\title{
Functional health literacy: protective role in adherence to treatment for hypertensive patients
}

\section{Letramento funcional em saúde: papel protetor na aderência ao tratamento de pacientes hipertensos}

\section{Alfabetización funcional en salud: el papel protector para la adhesión al tratamiento de pacientes con hipertensión}

\author{
Luciana Ricarte Cavalcante iD \\ Federal University of Bahia (Universidade Federal da Bahia - UFBA) - Salvador (BA) - Brazil \\ Luciara Leite Brito iD \\ Federal University of Bahia (Universidade Federal da Bahia - UFBA) - Salvador (BA) - Brazil \\ Helena Fraga-Maia iD \\ University of State of Bahia - (Universidade do Estado da Bahia - UNEB) - Salvador (BA) - Brazil
}

\begin{abstract}
Objective: To investigate factors associated with Functional Health Literacy (FHL), as well as its role as a probable protective factor for treatment adherence in individuals with hypertension (SAH), attended in Primary Health Care (Atenção Primária à Saúde - APS) units. Methods: This is a cross-sectional study with APS users under antihypertensive medication in the city of Salvador, Bahia. Illiterate or functionally illiterate patients were excluded, as well as those with a history of ischemic stroke. Data were collected between November 2015 and August 2016. Sociodemographic and clinical data were accessed utilizing a structured instrument developed by the authors, and the FHL was assessed using the REALM. Descriptive analyses and logistic regression were performed. Results: The population comprised 286 individuals and it was observed that low schooling was associated with inadequate $\mathrm{FHL}$, both in the gross and adjusted analysis (OR = 9.25; CI95\%: $4.49-19.05)$ and with the professional activity of manual labor $(\mathrm{OR}=9.90$; CI95\%: $2.08-46.90)$. In patients with schooling levels of over 8 years, it was observed that the FHL was significantly associated with non-adherence to medical treatment, even after adjustment by gender, age, civil status, physical activity, and skin color (OR = 3.0; Cl95\%: 1.2 - 7.9). Conclusions: Inadequate FHL was significantly associated with non-adhesion to treatment only for those with over 8 years of schooling. Improvements in health promotion actions should be reinforced to address chronic diseases such as SAH.
\end{abstract}

Descriptors: Health Literacy; Health Education; Hypertension; Treatment Adherence and Compliance.

\section{RESUMO}

Objetivo: Investigar os fatores associados ao letramento funcional em saúde (LFS), bem como seu papel como provável fator protetor para adesão à terapia em indivíduos com hipertensão (HAS) atendidos em unidades de Atenção Primária à Saúde (APS). Métodos: Estudo transversal realizado com usuários da APS em uso de medicamentos anti-hipertensivos na cidade de Salvador, Bahia, Brasil. Pacientes analfabetos ou analfabetos funcionais foram excluídos, assim como aqueles com história pregressa de acidente vascular cerebral. Coletaram-se os dados entre novembro de 2015 e agosto de 2016. Os dados sociodemográficos e clínicos foram acessados com instrumento estruturado desenvolvido pelos autores, e o LFS foi avaliado com o Rapid Estimate of Adult Literacy in Medicine (REALM). Realizaram-se análises descritivas e de regressão logística. Resultados: A população foi composta por 286 pessoas; e a baixa escolaridade estava associada à inadequação do LFS, tanto na análise bruta quanto na ajustada (OR = 9,25; IC95\%: 4,49 - 19,05), e com o tipo de atividade profissional de natureza manual (OR = 9,90; IC95\%: 2,08 - 46,90). Em pacientes com escolaridade acima de 8 anos, observou-se que o LFS se associou significativamente à não adesão ao tratamento médico, mesmo após ajuste por sexo, idade, estado civil, atividade física e cor da pele (OR = 3,0; IC95\%: 1,2 - 7,9). Conclusão: O LFS inadequado se associou significativamente à não adesão ao tratamento apenas para aqueles 
com escolaridade acima de 8 anos. Melhorias nas ações de promoção da saúde devem ser reforçadas ao lidar com doenças crônicas como a HAS.

Descritores: Letramento em Saúde; Educação em Saúde; Hipertensão; Cooperação e Adesão ao Tratamento.

\section{RESUMEN}

Objetivo: Investigar los factores asociados con la Alfabetización Funcional en Salud (AFS) y su papel como probable factor de protección para la adhesión al tratamiento de individuos con hipertensión (HAS) asistidos en unidades de Atención Primaria de Salud (APS). Métodos: Estudio transversal con usuarios de la APS en uso de medicación para la hipertensión en la ciudad de Salvador de Bahía. Los pacientes analfabetos y analfabetos funcionales han sido excluidos y aquellos con historias de accidentes vasculares cerebrales anteriores. Se ha recogido los datos entre noviembre de 2015 y agosto de 2016. Los datos clínicos y sociodemográficos han sido recogidos a través de un instrumento desarrollado por los autores y la AFS ha sido evaluada por el REALM. Se ha realizado los análisis descriptivo y de regresión logística. Resultados: La población fue de 286 individuos y la baja escolaridad estuvo asociada con la AFS inadecuada en el análisis bruto y el ajustado (OR = 9.25; IC95\%: 4.49 - 19.05) y con la actividad de trabajo manual (OR = 9.90; IC95\%: 2.08-46.90). En los pacientes con más de 8 años de escolaridad se observó que la AFS estuvo significativamente asociada con la no adhesión al tratamiento médico incluso después del ajuste para el género, la edad, el estado civil, la actividad física y el color de la piel (OR = 3.0; IC95\%: 1.2 - 7.9). Conclusión: La AFS inadecuada se asoció significativamente con la no adhesión al tratamiento solamente por aquellos con más de 8 años de escolaridad. Mejorías en las acciones de promoción de la salud deberían ser reforzadas para abordar enfermedades crónicas como la HAS.

Descriptores: Alfabetización en Salud; Hipertensión; Cumplimiento y Adherencia al Tratamiento.

\section{INTRODUCTION}

Functional Health Literacy (FHL) may be understood as the ability to read, interpret, make appropriate connections, and reproduce information within the health context ${ }^{(1-3)}$. Hence, the $\mathrm{FHL}$ level can interfere in the communication processes, in the perception, and the action of the individual concerning a commitment with the treatment, in other words, adhesion to therapy ${ }^{(4)}$. It is influenced by the understanding of all of its phases and the inherent risks of the health condition ${ }^{(3,5)}$. Long-term diseases, such as chronic non-communicable diseases (CNCD) tend to challenge health professionals in the sense of keeping their patients motivated and committed to their self-care ${ }^{(4,5)}$. The treatment of chronic diseases requires, therefore, the empowerment of adherence to medicinal treatment. The knowledge of the necessary care for keeping-up the well-being, despite the existence of a CNCD, such as Systemic Arterial Hypertension (SAH), is tied to understanding the importance of the treatment ${ }^{(4,6,7)}$.

Scientific evidence suggests that low FHL levels are related to low adhesion to treatment once there is a need for specific guidance ${ }^{(4,8)}$. Furthermore, recognizing the risks of complications resulting from the absence of blood pressure control may also influence the decision process for self-care in health. In the scope of Primary Healthcare, the National Humanization Policy presents the Singular Therapeutic Project (STP) as a healthcare organization strategy. The STP was developed with the proposal of the user being a part of the construction of the therapy to be adopted ${ }^{(9)}$ and, for this purpose, a low level of knowledge on the pathology and the treatment becomes a limiting factor ${ }^{(10)}$.

Consequently, it is considered that awareness that living habits and the correct intake of a medication influence the successful outcome of the treatment and also, that the FHL level interferes in the communication process and understanding of the treatment ${ }^{(7)}$. Nevertheless, despite being extensively discussed and related to health education processes in other countries ${ }^{(3,5)}$, there are few studies in Brazil assessing the relationship between FHL and adhesion to medicinal treatment. The purpose, therefore, is to investigate factors associated with Functional Health Literacy, as well as to its role as a probable protective factor for adhesion to therapy in individuals with systemic arterial hypertension treated at Primary HealthCare (Atenção Primária à Saúde - APS) units.

\section{METHODS}

A cross-sectional study was performed with individuals under treatment for the control of SAH at Primary HealthCare units in the Cabula- Beiru Health District (CBHD), in the city of Salvador, Bahia, Brazil. Patients over 18 years at the healthcare unit during the period of collection and under the use of hypertensive medication were invited to participate. The excluded patients were illiterate or functionally illiterate and those with a history of stroke. Patients, who after having started the data collection decided to withdraw, were considered as a loss. 
The sample calculation was performed using the OpenEpi (www.openepi.com) program. This program was based on the percentage of $24 \%$ for SAH in adults ${ }^{(11)}$, a sample error of $5 \%$, confidence level of $95 \%$, and CBHD population of 224,508 individuals for the age group of interest having estimated 280 individuals. The CBHD presents the fifth largest population density in the municipality of Salvador and serious public health issues associated to social determinants such as high levels of illiteracy and unemployment, low income and a high incidence of infectious and contagious diseases, such as tuberculosis and leprosy and, added to these, considerable cases of violence ${ }^{(12)}$.

Primary data was collected by trained researchers from November 2015 to August 2016. For data collection in the premises of the Primary Healthcare units, a structured form was used, prepared by the authors of the study, containing blocks of variables relating to sociodemographic, cultural, living habits, clinical history, treatment, and adhesion to treatment variables.

Concerning the sociodemographic variables, age in full years, and gender were questioned. Skin color was defined by the interviewer and classified following the Brazilian Institute of Geography and Statistics (Instituto Brasileiro de Geografia e Estatística - IBGE), but the analysis was collapsed to white and black/brown. Marital status was assessed considering the existence or absence of a partner. Schooling was defined following the years of study and characterized as less than eight and greater or equal to eight years. Family income was categorized as lower than two and equal to or greater than two minimum wages, which at the time of data collection the minimum wage was $\mathrm{R} \$ 880.00$. To occupational activity, the area of activity was classified as manual labor or not.

It was also included the verification of visual acuity using the Snellen chart, having considered as adequate for reading the signs, as a minimum, up to line $20 / 50$ of the chart without presenting signs or symptoms of visual problems $^{(13)}$.

To assess the FHL the Rapid Estimate of Adult Literacy in Medicine - REALM14 questionnaire was used ${ }^{(14)}$. The questionnaire consists of 66 items that assess the capacity of the individual to pronounce and understand common medical terms. When compared to other reading tests, the REALM test presented excellent concurrent validity, varying from 0.97 to $0.88(p<0.001) 15$. A pilot study was performed to calibrate the instruments and interviewers.

Regarding clinical data, the period of treatment for SAH was self-reported and registered in years. The existence of diagnosis for Diabetes Mellitus (DM) was questioned. Concerning self-care, the amount of different medication ingested in general was observed and the medication for blood pressure controlled. Adherence to treatment was investigated using the application of the Morisky-Green test (MGT) ${ }^{(15)}$ with four items and classified as adherent, moderately adherent and non-adherent, with the latter two collapsed for analysis. Regarding the use of the health services, it was computed whether the user attended or not the appointments. When investigating the communication processes and the perception of the guidance towards self-care, a clear understanding of the information was questioned and considered as dichotomous variables.

For data analysis, a Microsoft Excel for Windows databank was created and the analyses conducted on the Stata (V.12.0) statistical package, where corrections and inconsistencies eliminations were performed. To compare the FHL prevalence and assessment of the profile of adhesion to treatment, following the characteristics of the studied population, the chi-square test $(x 2)$ and $x 2$ for trend were applied. Bivariate analyses were performed to identify the set of variables that mostly contribute to the explanation of the FHL. For the preparation of the model, the variables that demonstrate levels of statistical significance, according to $<0.10$ were maintained. Subsequently, multivariate analyses were performed using logistic regression to estimate the association between FHL and adhesion to therapy, investigating potentially confounding and effect modification variables: age, skin color, schooling, marital status, income, occupation, professional activity, antihypertensive medication, period of SAH diagnosis, concomitant diabetes, missing appointments, understanding clearly all that is said during an appointment with the health professional, leaving the appointment without any doubts over the health situation, understanding all that is said before leaving the appointment, and leaving the appointment without any doubts as to the intake of medication. The magnitude of the association was estimated using the odds ratio (OR), adopting the $\mathrm{Cl}$ of $95 \%$.

This study is part of a greater project, called "Knowledge Multipliers: Junior Doctors and health education directed at family members and bearers of SAH and DM, residents in the Cabula/Beiru Health District" established in a partnership with the Education by Work for Health Program Pet Health/ Environmental and Sanitary Health Surveillance financed by the Ministry of Health in a partnership with the Municipal Health Department of Salvador and the State University of Bahia in 2012. It was approved by Plataforma Brasil/ CEP UNEB (Decision 241.434/2013). All of the participants signed the informed consent term and were informed that they could, at any time, interrupt or withdraw from the research. 


\section{RESULTS}

There were 286 individuals with $\mathrm{SAH}$ in the use of medical treatment who fulfilled the eligibility criteria.

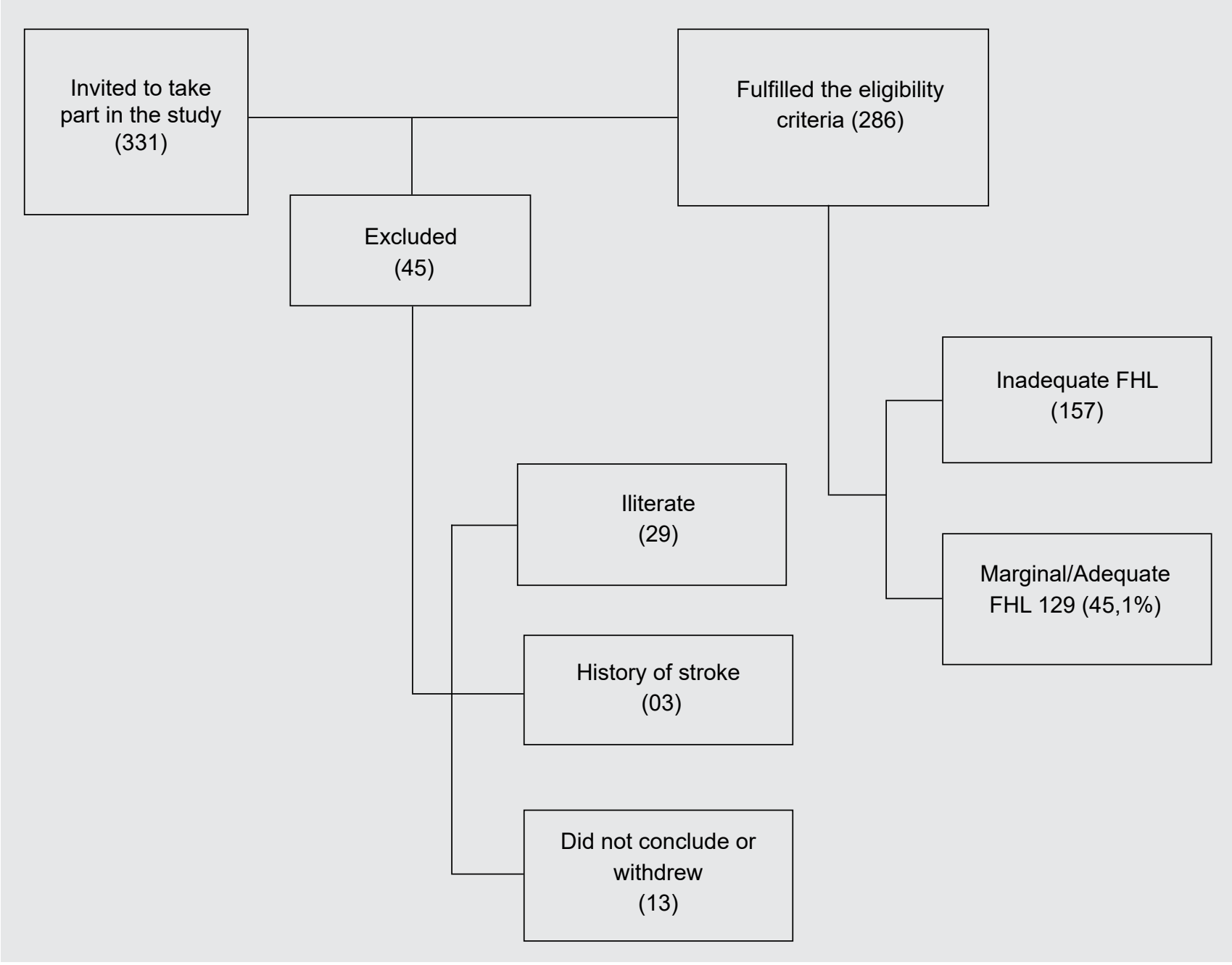

Figure 1 - Flowchart detailing the screening of patients for analysis

The sample was predominantly made up by individuals of the female gender $(82.2 \% ; n=235)$, aged under 60 years $(55.9 \%$; $n=160)$, skin color: black and brown $(94.4 \% ; n=270)$, and marital status of equal proportion (50.0\%; $n=143)$. There was also a predominance of low schooling $(62.9 \% ; n=180)$, low income $(65.1 \% ; n=186)$, professional occupation in manual labor activities $(89.8 \% ; n=257)$ and low adherence to treatment $(67.5 \% ; n=193)$. High prevalence of FHL were identified, with significantly different in relation to age groups (24 to 59 years $-61,9 \% ; n=78$ and 60 to 92 years 49,4\%; $n=79$ ), schooling (over 8 years of study $-22.6 \%$; $n=24$ and up to 8 years of study $-73.9 \%$; $n=133$ ), inserted in the labor market (yes - 43.2\%; n=35 and no - 59.5\%; n=122), professional activity (non-manual labor $6.9 \% ; n=2$ and manual labor $-60.3 \% ; n=155$ ) and concomitant diabetes (yes $-66.7 \% ; n=60$ and $n o-49.5 \% ; n=97$ ). It was observed that low schooling was associated to inadequate $\mathrm{FHL}$, both in the gross and the adjusted analyses (OR=9.25; Cl95\%: 4.49 - 19.05) and having a type of manual professional activity (OR=9.90; Cl95\%: 2.08 - 46.90).

Table II presents the characteristics of the individuals under adhesion to treatment. It was verified that among the patients who informed adherence to medical treatment, there was no significant difference to those who informed that they did not adhere to medical treatment concerning age, skin color, civil status, family income, type of occupational activity, continued use of antihypertensive medication, a period of diagnosis of hypertension and concomitant diabetes. It should be noted that patients who reported adherence to medical treatment are significantly higher proportions in the labor market $(31.6 \% ; n=61)$ compared to those who did not adhere $(21.5 \% ; n=20)(p=0.04)$ and those who did not clearly understand what was informed during the medical consultation $(30.1 \% ; n=58)$ compared to those who did not adhere to medical treatment $(19.4 \% ; n=18)(p=0.04)$. 
Table I - Prevalence of FHL in accordance with socio-demographic characteristics of treatment and self-care of patients with Systemic Arterial Hypertension attended at APS unit the Cabula-Beiru Health District. Salvador. Bahia, Brazil, 2016.

\begin{tabular}{|c|c|c|c|c|c|c|}
\hline Variables & $\begin{array}{c}n= \\
286\end{array}$ & $\%$ & $\begin{array}{c}\text { Prevalence of } \\
\text { inadequate } \mathrm{FHL}^{*} \\
(\%)\end{array}$ & $P$ value & $\begin{array}{l}\text { Gross OR } \\
(\mathrm{Cl} 95 \%)\end{array}$ & $\begin{array}{l}\text { Adjusted OR } \\
\text { (CI 95\%) }\end{array}$ \\
\hline \multicolumn{7}{|l|}{ Gender } \\
\hline Female & 235 & 82.2 & 54.5 & & 1.00 & 1.00 \\
\hline Male & 51 & 17.8 & 56.9 & 0.755 & $1.10(0.59-2.03)$ & $0.86(0.38-1.93)$ \\
\hline \multicolumn{7}{|l|}{ Age } \\
\hline 24 to 59 & 160 & 55.9 & 49.4 & & 1.00 & 1.00 \\
\hline 60 to 92 & 126 & 44.1 & 61.9 & 0.035 & $1.66(1.03-2.67)$ & $0.51(0.24-1.04)$ \\
\hline \multicolumn{7}{|l|}{ Skin color } \\
\hline White & 16 & 5.6 & 50.0 & & 1.00 & 1.00 \\
\hline Black and Brown & 270 & 94.4 & 55.2 & 0.685 & $1.23(0.44-3.37)$ & $1.77(0.46-6.82)$ \\
\hline \multicolumn{7}{|l|}{ Schooling } \\
\hline Over 8 years of schooling & 106 & 37.1 & 22.6 & & 1.00 & 1.00 \\
\hline Up to 8 years of schooling & 180 & 62.9 & 73.9 & 0.001 & $9.67(5.50-16.98)$ & $9.25(4.49-19.05)$ \\
\hline \multicolumn{7}{|l|}{ Marital status } \\
\hline Married or common-law marriage & 143 & 50.0 & 51.7 & & 1.00 & 1.00 \\
\hline $\begin{array}{l}\text { Single, widow(er), separated, } \\
\text { divorced }\end{array}$ & 143 & 50.0 & 58.0 & 0.285 & $1.29(0.81-2.05)$ & $1.88(1.00-3.56)$ \\
\hline \multicolumn{7}{|l|}{ Family income (minimum wages) } \\
\hline 2 or more minimum wages & 100 & 34.9 & 49.0 & & 1.00 & 1.00 \\
\hline Up to 1 minimum wage & 186 & 65.1 & 58.0 & 0.142 & $1.44(0.88-2.34)$ & $0.71(0.36-1.42)$ \\
\hline \multicolumn{7}{|l|}{ Working } \\
\hline Yes & 81 & 28.3 & 43.2 & & 1.00 & 1.00 \\
\hline No & 205 & 71.7 & 59.5 & 0.013 & $1.93(1.14-3.25)$ & $1.17(0.56-2.43)$ \\
\hline \multicolumn{7}{|l|}{ Professional activity } \\
\hline Non-manual labor & 29 & 10.2 & 6.9 & & 1.00 & 1.00 \\
\hline Manual labor & 257 & 89.8 & 60.3 & 0.001 & $20.51(4.77-8.14)$ & $9.90(2.08-46.9)$ \\
\hline \multicolumn{7}{|l|}{ Antihypertensive medication } \\
\hline$\leq 2$ & 262 & 91.6 & 54.9 & & 1.00 & 1.00 \\
\hline$>2$ & 24 & 8.4 & 54.1 & 0.940 & $0.96(0.42-2.24)$ & $1.00(0.35-2.83)$ \\
\hline \multicolumn{7}{|l|}{$\begin{array}{l}\text { Diagnosis time of Systemic Arterial } \\
\text { Hypertension (SAH) }\end{array}$} \\
\hline$\geq 5$ & 176 & 61.5 & 55.1 & & 1.00 & 1.00 \\
\hline$<5$ & 110 & 38.5 & 54.5 & 0.925 & $0.97(0.60-1.57)$ & $1.27(0.66-2.47)$ \\
\hline \multicolumn{7}{|l|}{ Concomitant diabetes } \\
\hline No & 196 & 68.5 & 49.5 & & 1.00 & 1.00 \\
\hline Yes & 90 & 31.5 & 66.7 & 0.007 & $2.04(1.21-3.43)$ & $1.40(0.71-2.77)$ \\
\hline
\end{tabular}

${ }^{*}$ FHL: Functional Health Literacy 
Table II - Association between Therapy adhesion and socio-demographic characteristics of treatment and self-care of patients with Systemic Arterial Hypertension attendee at APS unit in the Cabula-Beiru Health District. Salvador. Bahia, 2016. N=286.

\begin{tabular}{|c|c|c|c|c|c|}
\hline \multirow[t]{2}{*}{ Variables } & \multirow[t]{2}{*}{$\mathbf{n}$} & \multirow[t]{2}{*}{$(\%)$} & \multicolumn{2}{|c|}{$\begin{array}{c}\text { Therapy adhesion (Morisky- } \\
\text { Green) }\end{array}$} & \multirow{2}{*}{$P$ valor } \\
\hline & & & No (\%) & Yes (\%) & \\
\hline \multicolumn{6}{|l|}{ Age } \\
\hline 24 a 59 & 160 & 55.9 & 61.9 & 57.0 & \\
\hline 60 a 85 & 126 & 44.1 & 49.4 & 43.0 & 0.35 \\
\hline \multicolumn{6}{|l|}{ Skin color } \\
\hline White & 16 & 5.6 & 5.4 & 5.7 & \\
\hline Black and Brown & 270 & 94.4 & 94.6 & 94.3 & 0.57 \\
\hline \multicolumn{6}{|l|}{ Schooling } \\
\hline Over 8 years of schooling & 106 & 37.1 & 39.8 & 39.4 & \\
\hline Up to 8 years of schooling & 180 & 62.9 & 60.2 & 60.6 & 0.52 \\
\hline \multicolumn{6}{|l|}{ Marital status } \\
\hline Married or common-law marriage & 143 & 50.0 & 50.5 & 49.7 & \\
\hline Single, widow(er), separated, divorced & 143 & 50.0 & 49.5 & 50.3 & 0.50 \\
\hline \multicolumn{6}{|l|}{ Family income (minimum wages) } \\
\hline 2 or more minimum wages & 100 & 34.9 & 33.3 & 35.8 & \\
\hline Up to 1 minimum wage & 186 & 65.1 & 66.7 & 64.2 & 0.40 \\
\hline \multicolumn{6}{|l|}{ Working } \\
\hline Yes & 81 & 28.3 & 21.5 & 31.6 & \\
\hline No & 205 & 71.7 & 78.5 & 68.4 & 0.04 \\
\hline \multicolumn{6}{|l|}{ Professional activity } \\
\hline Non-manual labor & 29 & 10.2 & 7.5 & 11.4 & \\
\hline Manual labor & 257 & 89.8 & 92.5 & 88.6 & 0.31 \\
\hline \multicolumn{6}{|l|}{ Antihypertensive medication } \\
\hline$\leq 2$ & 262 & 91.6 & 91.4 & 91.7 & \\
\hline$>2$ & 24 & 8.4 & 8.6 & 8.3 & 0.54 \\
\hline \multicolumn{6}{|c|}{$\begin{array}{l}\text { Diagnosis time of Systemic Arterial Hypertension } \\
\text { (SAH) }\end{array}$} \\
\hline$\geq 5$ & 176 & 61.5 & 51.3 & 49.2 & \\
\hline$<5$ & 110 & 38.5 & 48.7 & 50.8 & 0.85 \\
\hline \multicolumn{6}{|l|}{ Concomitant diabetes } \\
\hline No & 196 & 68.5 & 62.4 & 71.5 & \\
\hline Yes & 90 & 31.5 & 37.6 & 28.5 & 0.08 \\
\hline \multicolumn{6}{|l|}{ Attends scheduled appointments } \\
\hline Yes & 251 & 87.8 & 69.9 & 76.7 & \\
\hline No & 35 & 12.2 & 23.3 & 30.7 & 0.14 \\
\hline \multicolumn{6}{|c|}{$\begin{array}{l}\text { Understands everything that is said during an } \\
\text { appointment }\end{array}$} \\
\hline Yes & 210 & 73.4 & 80.6 & 69.9 & \\
\hline No & 76 & 26.6 & 19.4 & 30.1 & 0.04 \\
\hline \multicolumn{6}{|c|}{$\begin{array}{l}\text { Leaves appointment with doubts about health } \\
\text { situation }\end{array}$} \\
\hline No & 215 & 75.2 & 81.7 & 73.6 & \\
\hline Yes & 71 & 24.8 & 17.3 & 26.4 & 0.20 \\
\hline \multicolumn{6}{|c|}{$\begin{array}{l}\text { Leaves appointment with doubts about how to } \\
\text { take medication }\end{array}$} \\
\hline No & 216 & 75.5 & 79.6 & 73.6 & \\
\hline Yes & 70 & 24.5 & 20.4 & 26.4 & 0.17 \\
\hline
\end{tabular}

*Variables with values of $p \leq 0.10$ integrate the multivariate logistic regression model.

A strong indication was identified between functional literacy and schooling $(p<0.001)$. Thus, the results of the association between functional literacy and adhesion to treatment were stratified by schooling levels. In patients 
with schooling levels of over 8 years, it was observed that inadequate functional literacy was significantly associated to non-adhesion to medical treatment, even after adjustment by gender, age, marital status, physical activity and skin color (OR=3.0; $95 \% \mathrm{Cl}: 1.2$ to 7.9 ), while in patients with schooling levels of up to 8 years, a positive association was observed between inadequate functional literacy and the non-adherence to treatment, although without statistical significance (OR=1.3; $95 \% \mathrm{Cl}$ : 0.6 to 2.9 ) (Table III).

Table III - Final model of association between Therapy adhesion and Inadequate Functional Health Literacy of patients with Systemic Arterial Hypertension cared for at cared for at APS unit in the Cabula-Beiru Health District. Salvador. Bahia, 2016. N=286

\begin{tabular}{lcc}
\hline & \multicolumn{2}{c}{ Inadequate Functional Health Literacy } \\
\cline { 2 - 3 } & Gross OR (CI 95\%) & Adjusted OR (CI 95\%) \\
\hline Schooling level & & \\
8 years and over & $1.4(0.6-2.9)$ & $1.3(0.6-2.9)$ \\
Up to 8 years & $2.2(0.9-5.4)$ & $1.3(0.6-2.9)$ \\
\hline
\end{tabular}

* Adjusted by Gender, Age, marital status, physical activity and skin color

\section{DISCUSSION}

The information in this study shows that inadequate Functional Literacy in Health was significantly associated with non-adherence to treatment only for those with schooling over 8 years. It is important to note that, in the present study, the estimated association between insufficient functional literacy in health and non-adherence to medical treatment was modified by the individuals' level of education. In this sense, the fact that individuals with a lower level of education have inadequate literacy shows the difficulty of the REALM instrument to discriminate functional literacy differentiators in this group to explain treatment adherence. Attention is drawn to the fact that no significant association was identified in this study between inadequate functional literacy and non-adherence to medical treatment in the group of individuals with low education. This finding can be explained, in part, by the remote possibilities of someone in the group having good reading skills.

According to the Functional Literacy Indicator (Indicador de Alfabetismo Funcional - INAF)(16), in 2016, among literate people or with a maximum of four years of study, a condition of functional illiteracy was observed in $67.0 \%$ of them. In addition, among these, only $1.0 \%$ was proficient. Thus, it appears that the lack of adequate schooling results in inadequate functional literacy and, consequently, in the inadequate LFS of this population stratum. It was observed that a large part of the population in this study had low education and, consequently, functional illiteracy. Many users were barely able to write their own names, despite informing a higher level of education, considering that, when asked to read the phrase "Close your eyes" in the Mini-Mental State Examination (MMSE), they reported that they could only sign their own name.

The finding in the group with schooling above 8 years that there was a positive and statistically significant association of inadequate functional literacy in health and non-adherence to treatment allows determining that literacy is one of the important factors for adherence to treatment, mainly because in this group individuals have the reading ability, which allows them to adequately measure literacy. In this sense, low health literacy rates can result in greater difficulty in accessing verbal and written information, such as medical prescriptions and other guidelines. This acts as a gap in the communication process and the information provided may be perceived in a different way than the original or may not even be obtained. As a result, misinterpretations in understanding may occur and affect the application of such information during self-care ${ }^{(7,17)}$. Therefore, this causes low adherence to therapy, resulting in a lack of blood pressure control and greater exposure to complications and comorbidities ${ }^{(6,17)}$.

In addition to these findings are the results observed for a better understanding and allow the person to understand and act on health information with certain autonomy. Furthermore, researchers ${ }^{(1)}$ reported that in addition to the influence of the level of $\mathrm{FHL}$, in the health communication process, the personalities involved in the doctorpatient binomial can affect the relationship and the approach of the language used, generating an incompatibility of information. In this present study, interviewees reported that they were often ashamed of not understanding the information provided and, on many occasions, they did not consult the professionals imagining that they would not have the patience to explain in detail what they had said.

It is estimated that the association between adequate $\mathrm{FHL}$ and adhesion to treatment may be justified by the Charles Maguerez ${ }^{(18,19)}$ arc theory, in other words, through the process that involves the decision-making ark which is required for self-care. The need for identification of the difficulties (observation of reality) that can be perceived 
by the individual is considered, as well as the influence of the beliefs of the individual during the observation of the individual's context, which implies in the preparation of theories about the problem (identification of key issues). Consequently, access to adequate information, at this time, can favor an understanding of the health situation of the individual (theorization) and the preparation of hypotheses (solution hypotheses), and accessible strategies following the reality of the individual (application to reality) (20-22). In the present study, a gap was also observed in the health communication processes and such fact reinforces the hypothesis that this may also be a probable justification for these findings.

Adherence to treatment investigated herein is understood as being the degree of agreement between the guidance offered for the medical treatment and the adoption of such guidance ${ }^{(23,24)}$. It is a fact that adhesion to medication can suffer interferences from involuntary factors such as cognitive alterations, forgetfulness, or even socioeconomic factors that can impact the acquisition of medication ${ }^{(24,25)}$. Despite income not having been considered as an important variable in this study in the association between inadequate Functional Health Literacy and non-adherence to treatment, this has been demonstrated in other studies. Findings of an investigation in a study ${ }^{(26)}$ with cardiovascular patients in an outpatient clinic in Juiz de Fora, Minas Gerais, Brazil, showed that individuals receiving up to one minimum wage presented greater difficulties in controlling the timing for taking their medication. Furthermore, they had difficulties in following the guidance related to diets and physical activities due to not fully understanding such guidance. In a global context, various studies have pointed out that socioeconomic factors and schooling levels are proxy variables and both related to the level of $\mathrm{FHL}^{(20-22)}$. This influences important aspects involved in the process of adherence to treatment and the self-care capacity ${ }^{(22,24)}$.

It is important to mention that strategies to improve adherence to treatment depend on the identification of factors that go beyond functional literacy. Considering that, in this study, inadequate Functional Literacy in Health had a relevant role in non-adherence to treatment; the identification of factors associated with inadequate Functional Literacy in Health can be useful in the recognition of risk groups for non-adherence to treatment. Among the factor investigated, the emphasis is given to schooling levels and professional activity. The fact of being a manual laborer was strongly associated with inadequate functional health literacy. It is important to observe that among the factors significantly associated with inadequate $\mathrm{FHL}$, the professional activity, and type of activity, whether manual labor or not, is also related to the level of understanding of the individual due to a lower schooling level. In a research ${ }^{(27)}$ it was highlighted that the premature entrance of low-income young people to the labor market may be related to a lower schooling level.

As such, it is assumed that early beginning in the labor activity may be associated with the rendering of professional services that do not demand formal education. A similar result was observed in a study ${ }^{(28)}$ when investigating the perspective of elderly people using the health care services and observing that most had not concluded elementary school and also made reference to the historical late entrance of women to the school environment within the social context of Brazil. Similar to the latter case, in the present study the population was predominantly of the female gender, and during the investigation reports were also received that they were not permitted to attend school once they were not authorized by family members, parents, and/or partners.

In the present study factors such as gender and age were not demonstrated as risk factors associated with low FHL, despite some investigators have pointed out this connection. In a research performed in the USA ${ }^{(3)}$, it was observed that women presented a better performance in FHL tests when compared to men. However, in another study ${ }^{(29)}$ carried out in Portugal, it was observed that women had a higher risk of presenting a limited FHL. It is thus observed that there is no consensus in the literature concerning the influence of gender and the level of functional literacy. Nevertheless, it is considered that socioeconomic and age group variations of these individuals could justify these different findings. About age, the results obtained by a study of literature review ${ }^{(30)}$ observed that the FHL was associated with sociodemographic variables such as gender, age, and schooling levels. However, in another research ${ }^{(31)}$, performed in Goiás, Brazil, despite not identifying the association between $\mathrm{FHL}$ and age, higher health fragility was observed in the elderly. Furthermore, in a study ${ }^{(32)}$, it was suggested that cognitive alterations associated with senility could interfere in the findings related to FHL.

The partnership established with the Municipal Health Department was considered an advantage, as well as the considerable availability of health unit leaders to collaborate with the study. The primary data collected in person and applied by trained interviewers, as well as the pilot study, can also be considered as strong points of this investigation.

Limitation factors considered were the large variety of instruments to assess the FHL construct, suggesting a multiplicity of intervening factors and requiring greater attention for the comparison of results and the use of an instrument not validated for the Portuguese language. However, REALM is an instrument of simple application and the use of the non-validated instrument is of simple application and comprises words that are related to the healthcare 
routine. Consequently, the free translation may not compromise once it is similar to the constructs presented in the original instrument. The use by other Brazilian researchers in the development of investigations with similar populations is also emphasized.

The importance of the findings of this research resides in the strong recommendation of clearer guidelines for the approach of hypertensive users with low education and even for those with more than 8 years of study. Constantly checking, at each consultation, the understanding of the guidelines offered and the need to adhere to conservative and medication treatment should be a concern for all health professionals. It is also recommended that new studies be carried out for a better understanding of the phenomena reported herein. For now, it is suggested that strategies be adopted to verify the efficiency of the communication processes during medical care to patients with non-communicable chronic diseases care for at primary healthcare units.

\section{CONCLUSION}

The results of the study permit us to conclude that inadequate FHL was significantly associated with non-adhesion to treatment only for patients with over 8 years of schooling. However, despite the results suggesting that for individuals with low schooling functional literacy was not significantly associated with non-adhesion to treatment, the schooling level influenced the degree of FHL and, therefore, on the process of adhesion to medical therapy. For that reason, improvement to health promotion actions should be strengthened when addressing chronic diseases such as SAH.

\section{CONFLICTS OF INTEREST}

There are no conflicts of interest.

\section{CONTRIBUTIONS}

Luciana Ricarte Cavalcante and Helena Fraga-Maia contributed to the study conception and design; analysis and interpretation of data and writing and revision of the manuscript. Luciara Leite Brito contributed to analysis and interpretation of data; and writing the manuscript.

\section{REFERENCES}

1. İlgün G, Turaç iS, Orak S. Health literacy. Procedia Soc Behav Sci [Internet] 2015 [accessed on 2020 Apr 2];(174):2629-33. Available from: https://core.ac.uk/download/pdf/82010742.pdf

2. Duong TV, Chang PW, Yang SH, Chen MC, Chao WT, Chen T, et al. A New Comprehensive Shortform Health Literacy Survey Tool for Patients in General. Asian Nurs Res [Internet]. 2017 [accessed on 2020 Apr 4];11(1):30-5. Available from: https://www.asian-nursingresearch.com/article/S19761317(17)30070-1/fulltext

3. Halladay JR, Donahue KE, Cené CW, Li Q, Cummings DM, Hinderliter AL, et al. The association of health literacy and blood pressure reduction in a cohort of patients with hypertension: the heart healthy lenoir trial. Patient Educ Couns [Internet]. 2017 [accessed on 2020 Apr 2];100(3):542-9. Available from: https://pubmed. ncbi.nlm.nih.gov/27776790/?from_single_result=Health+literacy+and+blood+pressure+reduction+in+a+cohort \&expanded_search_query=Health+literacy+and+blood+pressure+reduction+in+a+cohort

4. Náfrádi L, Galimberti E, Nakamoto K, Schulz PJ. Intentional and unintentional medication non-adherence in hypertension: the role of health literacy, empowerment and medication beliefs. J Public Health Res [Internet]. 2016 [accessed on 2020 Apr 5];5(3):762: 111-5. Available from: https://www.ncbi.nlm.nih.gov/pmc/articles/ PMC5206775/pdf/jphr-2016-3-762.pdf

5. McNeil A, Arena R. the evolution of health literacy and communication: introducing health harmonics. Prog Cardiovasc Dis [Internet]. 2017 [accessed on 2020 Apr 2];59(5):463-70. Available from: https://reader.elsevier. $\mathrm{com} / \mathrm{reader} / \mathrm{sd} / \mathrm{pii} / \mathrm{S} 0033062017300269$ ?token=03D7A073B7F776ED3F91398C03B6F4FB4E285460626BAC 2B7569F4796E6C4B1EABDB01253905A8D077D8B033FA929980

6. Falcão AS, Silva MGC, Rodrigues AF Jr, Moura SR, Silva FRS, Sousa ASJ, et al. Estilo de vida e adesão ao tratamento de hipertensão arterial sistêmica em homens idosos. Rev Bras Promoç Saúde [Internet]. 2018 [accessed on 2020 Apr 2];31(2):1-10. Available from: https://periodicos.unifor.br/RBPS/article/view/7402/pdf 
7. Tavakoly Sany S, Behzhad, F, Ferns G, Peyman N. Communication skills training for physicians improves health literacy and medical outcomes among patients with hypertension: a randomized controlled trial. BMC Health Serv Res [Internet]. 2020 [accessed on 2020 Apr 2];20(60):1-10. Available from: https:// bmchealthservres.biomedcentral.com/track/pdf/10.1186/s12913-020-4901-8

8. Beraldo PC, Moysés ST, Werneck RI, Araujo ES, Moysés SJ. Educational approaches focusing on the quality of life of people with chronic kidney disease receiving hemodialysis: an integrative review. Fisioter Mov [Internet]. 2017 [accessed on 2020 Apr 12];30(3):595-605. Available from: http://www.scielo.br/scielo. php?script=sci_arttext\&pid=S0103-51502017000300595\&Ing=en

9. Silva AI, Loccioni MFL, Orlandini RF, Rodrigues J, Peres GM, Maftum MA. Projeto terapêutico singular para profissionais da estratégia de saúde da família. Cogitare Enferm [Internet]. 2016 [accessed on 2020 Apr 2];21(3):1-8. Available from: https://revistas.ufpr.br/cogitare/article/view/45437/pdf

10. Costa VRS, Costa PDR, Nakano EY, Apolinário D, Santana ANC. Functional health literacy in hypertensive elders at primary health care. Rev Bras Enferm [Internet]. 2019 [accessed on 2020 Apr 2];72(Suppl2):266-73. Available from: http://www.scielo.br/scielo.php?script=sci_arttext\&pid=S003471672019000800266\&lng=en. Epub Dec 05, 2019

11. Ministério da Saúde (BR), Secretaria de Atenção à Saúde, Departamento de Atenção Básica. Estratégias para o cuidado da pessoa com doenças crônicas nas redes de atenção e nas linhas de cuidado prioritárias [Internet]. Brasília: Ministério da Saúde; 2013 [accessed on 2019 Sept 15]. Available from: https://bvsms. saude.gov.br/bvs/publicacoes/diretrizes\%20_cuidado_pessoas\%20_doencas_cronicas.pdf

12. Prefeitura Municipal de Salvador, Secretaria Municipal da Saúde, Diretoria Estratégica de Planejamento e Gestão. Plano Municipal de Saúde do Salvador 2018-2021 [Internet]. Salvador: Prefeitura Municipal de Salvador; 2018 [accessed on 2020 apr 6]. Available from: http://www.saude.salvador.ba.gov.br/secretaria/ informativos-e-documentacoes/

13. Park Y, Shin JA, Yang SW, Yim HW, Kim HS, Park Y-H, et al. The Relationship between Visual Impairment and Health-Related Quality of Life in Korean Adults: The Korea National Health and Nutrition Examination Survey (2008-2012). PLoS ONE [Internet]. 2015 [accessed on 2015 dec 15];10(7): e0132779. Available from: https://journals. plos.org/plosone/article/file?id=10.1371/journal. pone.0132779\&type=printable

14. Sawkin MT, Deppe SJ, Thelen J, Stoner SC, Dietz CA, Rasu RS. Health Literacy and Medication Adherence Among Patients Treated in a Free Health Clinic: A Pilot Study. Health Serv Res Manag Epidemiol [Internet]. 2015 [accessed on 2016 jan 10]. Available from: https://www.ncbi.nlm.nih.gov/pmc/articles/PMC5266426/ pdf/10.1177_2333392815589094.pdf

15. Pandey A, Raza F, Velasco A, Brinker S, Ayers C, Das SR, et al. Comparison of Morisky Medication Adherence Scale with therapeutic drug monitoringin apparent treatment resistant hypertension. J Am Soc Hypertens [Internet]. 2015 [accessed on 2015 dec 10];9(6):420-6. Available from: https://reader.elsevier.com/ reader/sd/pii/S1933171115004623?token=DFF9FFCE2EE29EB6F046AE551CE4DE54896F0DF52EBB873F6 8C5F3929D8922B90A18FEF60D6822A160DB7BD35CA12506

16. Instituto Paulo Montenegro. Indicador de Alfabetismo Funcional - INAF: Estudo especial sobre alfabetismo e mundo do trabalho [Internet]. São Paulo: IPM; 2016 [accessed on 2017 Jan 20]. Available from: http:// acaoeducativa.org.br/wp-content/uploads/2016/09/INAFEstudosEspeciais_2016_Letramento_e_Mundo_do_ Trabalho.pdf

17. Mafutha NG, Mogotlane S, Swardt HC. Development of a Hypertension Health Literacy Assessment Tool for use in primary healthcare clinics in South Africa, Gauteng. Afr J Prim Health Care Fam Med [Internet]. 2017 [accessed on 2019 Feb 10];27;9(1):e1-e8. Available from: https://www.ncbi.nlm.nih.gov/pmc/articles/ PMC5566124/

18. Prado ML, Velho MB, Espíndola DS, Sobrinho SH, Backes VMS. Arco de Charles Maguerez: refletindo estratégias de metodologia ativa na formação de profissionais de saúde. Arco de Charles Maguerez: refletindo estratégias de metodologia ativa na formação de profissionais de saúde. Esc Anna Nery [Internet]. 2012 [accessed on 2020 mar 15]; 16(1):172-7. Available from: http://www.scielo.br/scielo.php?script=sci arttext\&pid=S1414-81452012000100023\&Ing=en 
19. Brandão ERM, Rocha SV, Silva SS. Práticas de Integração Ensino-Serviço Comunidade: Reorientando a Formação Médica. Rev Bras Educ Med [Internet]. 2013 [accessed on 2020-04-12];37(4):573-7. Available from: http://www.scielo.br/scielo.php?script=sci_arttext\&pid=S0100-55022013000400013\&lng=en\&nrm=iso

20. Sampaio HAC, Silva DMA, Sabry MOD, Carioca AAF, Chayb APV. Letramento nutricional: desempenho de dois grupos populacionais brasileiros. Brazilian Soc. Food Nutr [Internet]. 2013 [accessed on 2020 Apr 12];38(2):144-55. Available from: http://sban.cloudpainel.com.br/files/revistas_publicacoes/391.pdf

21. Santos LTM, Mansur HN, Paiva TFPS, Colugnati FAB, Bastos MG. Letramento em Saúde: Importância da avaliação em nefrologia. J Bras Nefrol [Internet]. 2012 [accessed on 2020 Mar 18];34(3):293-302. Available from: http://www.scielo.br/scielo.php?script=sci_arttext\&pid=S0101-28002012000300014\&lng=en

22. Batterham RW, Hawkins M, Collins PA, Buchbinder R, Osborne RH. Health literacy: applying current concepts to improve health services and reduce health inequalities. Public Health [Internet]. 2016 [accessed on 2020 Mar 18];132:3-12. Available from https://reader.elsevier.com/reader/sd/pii/S0033350616000044?toke $\mathrm{n}=\mathrm{C} 39 \mathrm{~B} 8 \mathrm{BFCF}$ CDD9DE7BD0263BE3735DD48649E1E774AF05759E4DBA39C52A27596C45392AC4BE60 02EACEBE874FE02D69

23. Ruppar TM, Dunbar-Jacob JM, Mehr DR, Lewis L, Conn VS. Medication adherence interventions among hypertensive black adults: a systematic review and meta-analysis. J Hypertens [Internet]. 2017 [accessed on 2020 Mar 18];35(6):1145-54. Available from: https://pubmed.ncbi.nlm.nih.gov/28106662/

24. Macquart de Terline D, Kane A, Kramoh KE, Ali Toure I, Mipinda JB, Diop IB, et al. Factors associated with poor adherence to medication among hypertensive patients in twelve low and middle income Sub-Saharan countries. PLoS ONE [Internet]. 2019 [accessed on 2020 Mar 20];14(7):e0219266. Available from: https:// www.ncbi.nlm.nih.gov/pmc/articles/PMC6619761/pdf/pone.0219266.pdf

25. Brown MT, Bussell J, Dutta S, Davis K, Strong S, Mathew S. Medication adherence: truth and consequences. Am J Med Sci [Internet]. 2016 [accessed on 2020 Mar 18];351(4):387-99. Available from: https://www. amjmedsci.org/article/S0002-9629(15)37996-9/fulltext

26. Chehuen JÁ Neto, Costa LA, Estevanin GM, Bignoto TC, Vieira CIR, Pinto FAR, et al. Letramento funcional em saúde nos portadores de doenças cardiovasculares crônicas. Ciênc Saúde Colet [Internet]. 2019 [accessed on 2020 Apr 2];24(3):1121-32. Available from: http://www.scielo.br/scielo.php?script=sci_ arttext\&pid=S1413-81232019000301121\&lng=en

27. Passamai MPB, Sampaio HAC, Dias AMI, Cabal LA. Letramento funcional em saúde: reflexões e conceitos sobre seu impacto na interação entre usuários, profissionais e sistema de saúde. Interface (Botucatu) [Internet]. 2012 [accessed on 2020 Apr 2];16(41):301-14. Available from: http://www.scielo.br/scielo. php?script=sci_arttext\&pid=S1414-32832012000200002\&lng=en

28. Torquato R, Massi G, Santana AP. Envelhecimento e letramento: a leitura e a escrita na perspectiva de pessoas com mais de 60 anos de idade. Psicol Reflex Crit [Internet]. 2011 [accessed on 2020 Apr 2];24(1):89-98. Available from http://www.scielo.br/scielo.php?script=sci_arttext\&pid=S0102$79722011000100011 \&$ Ing=en\&nrm=iso

29. Cunha M, Gaspar R, Fonseca S, Almeida D, Silva M, Nunes L. Implications of literacy for health for body mass index. Aten Primaria [Internet]. 2014 [accessed on 2020 Apr 2];46(Espec Cong 1):180-6. Available from: https://reader.elsevier.com/reader/sd/pii/S0212656714700885?token=051D87177EE43452A8771D6D9E2E04 9627291F3DB663E82667A0D0773D943A3110D53DD8EA83485AEB21429E7629AF95

30. Rocha PC, Lemos SMA. Letramento em saúde: Revisão. Rev CEFAC [Internet]. 2016 [accessed on 2020 Apr 5];18(1):214-25. Available from: http://www.scielo.br/pdf/rcefac/v18n1/1982-0216rcefac-18-01-00214.pdf

31. Santos JEM, Brasil VV, Moraes KL, Cordeiro JABL, Oliveira GF, Bernardes CP, et al. Comprehension of the education handout and health literacy of pacemaker users. Rev Bras Enferm [Internet]. 2017 [accessed on 2020 Apr 4];70(3):633-9. Available from: http://www.scielo.br/scielo.php?script=sci_arttext\&pid=S0034$71672017000300633 \&$ Ing $=$ en 
32. Kaphingst KA, Goodman MS, MacMillan WD, Carpenter CR, Griffey RT. Effect of cognitive dysfunction on the relationship between age and health literacy. Pat Educ Couns [Internet]. 2014 [accessed on 2020 Apr 4];95(2):218-25. Available from: https://www.ncbi.nlm.nih.gov/pmc/articles/PMC4172373/pdf/ nihms-618933.pdf.

\section{Mailing address:}

Luciana Ricarte Cavalcante

Instituto de Saúde Coletiva da Universidade Federal da Bahia

Rua Basílio da Gama, s/n

Bairro Canela

CEP: 40110-040 - Salvador - Bahia - Brasil

E-mail: lucianaricarte@gmail.com

How to cite: Cavalcante LR, Brito LL, Fraga-Maia H. Functional health literacy: protective role in adherence to treatment for hypertensive patients. Rev Bras Promoç Saúde. 2020;33:10503. 